\title{
A kártyás fizetési mód területi jellemzői Magyarországon*
}

\author{
Kajdi László - Nemecskó István
}

A kártyás fizetések jelenleg a kiskereskedelemben a legfontosabb alternativát jelentik a társadalmi szempontból, hosszú távon kedvezőtlenebb készpénzzel szemben. A hazai elektronikus pénzforgalom fejlődési lehetőségeivel a korábbi tanulmányok jellemzően csak országos szinten foglalkoztak. Tanulmányunkban korábban nem elérhető adatok segítségével a kártyás fizetési mód hazai területi jellemzőit vizsgáljuk meg a kártyás fizetések infrastruktúrájára és használatára ható tényezök azonosításával. Eredményeink azt mutatják, hogy a kisebb településeken kevésbé fejlett az elfogadói hálózat és alacsonyabb a kártyabirtoklás, míg a régiókat tekintve a POS-hálózatnál Észak-Magyarország és Közép-Dunántúl, a kártyabirtoklásnál pedig az alföldi megyék esetében kedvezőtlenebb a kép. A kártyahasználatra az elfogadói hálózat fejlettsége mellett a munkaerőpiaci helyzet van szignifikáns hatással. Az eredmények megerősítik a kártyaelfogadói hálózat fejlesztésének fontosságát - például állami programokkal -, valamint felhívják a figyelmet arra, hogy a kisebb településeken és az elmaradottabb régiókban továbbra sem elég fejlett a kártyás fizetési mód.

Journal of Economic Literature (JEL) kódok: G20, D12, R11

Kulcsszavak: pénzforgalom, kártyaelfogadás, területi jellemzők

\section{Bevezetés}

Az elektronikus pénzforgalom térnyerésének és a készpénzhasználat visszaszorításának előnyeit számos tanulmány hangsúlyozta már, mind Magyarországon, mind nemzetközi szinten. Ahogy többek között Benedek et al. (2013) is bemutatja, a szürkegazdaság mérésére szolgáló közvetett mutatókban és mérésekben gyakran alkalmazzák a makroszintű készpénzkeresleti adatokat, mivel a rejtett gazdaság tranzakciói jellemzően ilyen módon bonyolódnak le. Az adóelkerülést csökkentheti a készpénzhasználat visszaszorulása, ahogy azt nemzetközi szinten is számos tanulmány bizonyította már (például Braithwaite et al. 2002; Rogoff 2017), ugyanakkor más vizsgálatok alapján ez az összefüggés nem egyértelmű. Seitz et al. (2018) szerint

\footnotetext{
* A jelen kiadványban megjelenő írások a szerzők nézeteit tartalmazzák, ami nem feltétlenül egyezik a Magyar Nemzeti Bank hivatalos álláspontjával.

Kajdi László a Magyar Nemzeti Bank vezető közgazdasági elemzője. E-mail: kajdil@mnb.hu Nemecskó István a Magyar Nemzeti Bank junior elemzóje. E-mail: nemecskoi@mnb.hu

A magyar nyelvű kézirat első változata 2019. szeptember 12-én érkezett szerkesztőségünkbe.

DOI: http://doi.org/10.25201/HSZ.19.1.6589
} 
csak a közepes címletű bankjegyek és a kisebb eurozónás országok esetében áll fent kapcsolat, míg a Deutsche Bundesbank (2019) tanulmánya arra hívja fel a figyelmet, hogy más fizetési módokat is használnak a szürkegazdaságban, valamint a nagy címletű bankjegyek esetében sokkal inkább domináns a megtakarítási funkció, mint a különböző illegális célok. Más szempontból közelítették meg a készpénzhasználat hátrányait azok a jegybanki tanulmányok (Turján et al. 2011; Schmiedel et al. 2012), amelyek a készpénzhasználat magas társadalmi költségeire hívták fel a figyelmet. Rövid távon vélhetően a készpénzes fizetés költségei is alacsonyak, azonban egy bizonyos kritikus szint elérése után, hosszú távon magasabbak a társadalmi költségei, mint az elektronikus fizetéseknek.

Mindezek a tényezők a legtöbb országban, így Magyarországon is arra sarkallják az állami és jegybanki döntéshozókat, hogy a készpénz helyett az elektronikus fizetési módok növekvő használatát ösztönözzék, illetve biztosítsák minden fizetési helyzetben a fizetési módok közötti szabad választást. Fontos ugyanakkor, hogy ez utóbbi kitétel egyes készpénzt kevéssé használó országokban (pl. Svédországban) azt is jelenti, hogy a készpénzes fizetés biztosítását is előírják kereskedőknek vagy bankoknak. Ahogy azt Ilyés - Varga (2015) is bemutatta tanulmányában, jelenleg a lakossági fizetési tranzakciók több mint háromnegyede bonyolódik le készpénzben, ami ugyan nem tér el jelentősen a legtöbb európai országban tapasztalható aránytól (Esselink - Hernandez 2017), azonban jelzi, hogy jelentős tér van még a javulásra ezen a téren. Az azonnali fizetések bevezetése a legtöbb országban nagy lökést adhat az elektronikus fizetési módok térnyerésének, jelenleg azonban a készpénz legfőbb versenytársa a kiskereskedelmi tranzakciók terén a fizetési kártya. Ennek a használatát és elfogadását befolyásoló tényezőket, így többek között a bankközi jutalékok nagyságát, a felárazás kérdését számos tanulmány vizsgálta külföldön és Magyarországon is (Greene - Stavins 2018; Ilyés - Varga 2018; Jonker et al. 2018; Rochet - Tirole 2003).

A rendelkezésre álló adatok hiányában ugyanakkor ez idáig kevés elemzés koncentrált a lakossági pénzforgalom területi eltéréseire. Helmeczi (2010) elsősorban az átutalási és csoportos beszedési forgalom, valamint az infrastruktúra (ATM-ek, POS-terminálok, bankfiókok) területi eloszlásának sajátosságaira fókuszált. A bankfióki ellátottság vonatkozásában a legrosszabb helyzetben Vas, Veszprém és Nógrád megye lakosai voltak, míg Budapesten jellemzően a központi kerületekben koncentrálódnak a fiókok. A lakossági ügyfelek által még gyakrabban igénybe vett készpénzfelvevő automaták (ATM-ek) 1000 lakosra jutó aránya Pest és Borsod-Abaúj-Zemplén megye mellett főleg az Alföldön alacsony, és hasonló a helyzet a kereskedői POS-terminál-lefedettséggel is, ami a már említett alföldi megyék mellett Nógrádban és Szabolcsban volt a legrosszabb. Az átutalási és a csoportos beszedési forgalom tekintetében a hazai elszámolóházon, a GIRO Zrt-n keresztül lebonyolított bankközi tranzakciók kerültek csak elemzésre, ami szükségképpen korlátozott képet 
mutathat csak, mivel kimaradnak a hazai bankok belső tételei. Más tanulmányok (Pál 2014; Kuttor - Pál 2019) szintén a bankközi átutalási és beszedési forgalmat vizsgálták hálózati szempontból. Ezek alapján a bankközi forgalom körülbelül 40 százaléka településen belül bonyolódik le, és Budapest szerepe kitüntetett a hazai pénzforgalmi hálózatban, ugyanakkor regionális központok is azonosíthatók. Kovács (2017) tanulmányában a bankfiók-ellátottságot és -hozzáférhetőséget vizsgálta, és szintén rámutat a városok, megyei jogú városok és kisebb települések közötti különbségekre. Ilyés - Varga (2015), valamint Végső et al. (2018) a lakossági számla- és kártyabirtoklást, valamint fizetési szokásokat településtípusonként vizsgálta. Mindkét felmérés eredménye az volt, hogy Budapesten magasabb a kártyalefedettség, valamint az elektronikus fizetési módok használata. Ilyés - Varga (2018) online-pénztárgép-adatokon végzett vizsgálata szintén a főváros jelentőségét emeli ki a kártyaelfogadás tekintetében.

A Helmeczi (2010) elemzése óta eltelt közel 10 évben jelentős fejlődés történt a hazai pénzforgalmi infrastruktúrában, ami - elsősorban a fizetési kártyás - forgalomban is számottevő bővülést eredményezett. A Magyar Nemzeti Bank (MNB 2019) adatai szerint a természetes személyek által birtokolt fizetési számlák tekintetében ez ugyan kevésbé mutatkozott meg, mivel a számlaellátottság már 2010 végén is magasnak volt mondható (mintegy 9,4 millió darab), így ezen a téren mérsékelt 3,3 százalékos növekedés látható 2010. és 2018. év vége között. Ehhez hasonló a helyzet a lakosság kártyaellátottsága tekintetében, amely a 3,9 százalékos bővülés eredményeként 8,7 millió darab lakossági kártyát jelentett 2018. december 31-én. Eszközoldalról a hazai ATM-hálózat 5 százalékkal bővült, ugyanakkor a POS-terminálok száma a kérdéses időszakban jelentősen, több mint kétszeresére (2,17-szeresére) nőtt. Mindez azt is jelenti, hogy a kártyahasználat is sokkal intenzívebb lett a lakosság körében, a kártyás vásárlások éves növekedési üteme 20-25 százalék, és a 2010. évi 198 millió darab vásárláshoz képest a 2018-ban lebonyolított több mint 765 millió darab tranzakció közel négyszeres emelkedést jelent.

Európai összehasonlításban elmondható, hogy a kiskereskedelmi elektronikus elfogadói hálózat tekintetében van még tér a bővülésre. Mivel jelen pillanatban a fizikai elfogadóhelyek esetében szinte kizárólagosan a kártyás fizetés jelenti az elektronikus fizetési lehetőséget, ezért ez jól vizsgálható a POS-terminál-ellátottsággal az egyes országokban. Az Európai Központi Bank adatai szerint (1. ábra) Magyarország ebből a szempontból a rangsor utolsó harmadában foglal helyet, ami egyúttal jól jelzi a pénzforgalmi szolgáltatók számára kínálkozó üzleti lehetőséget is ezen a téren. 


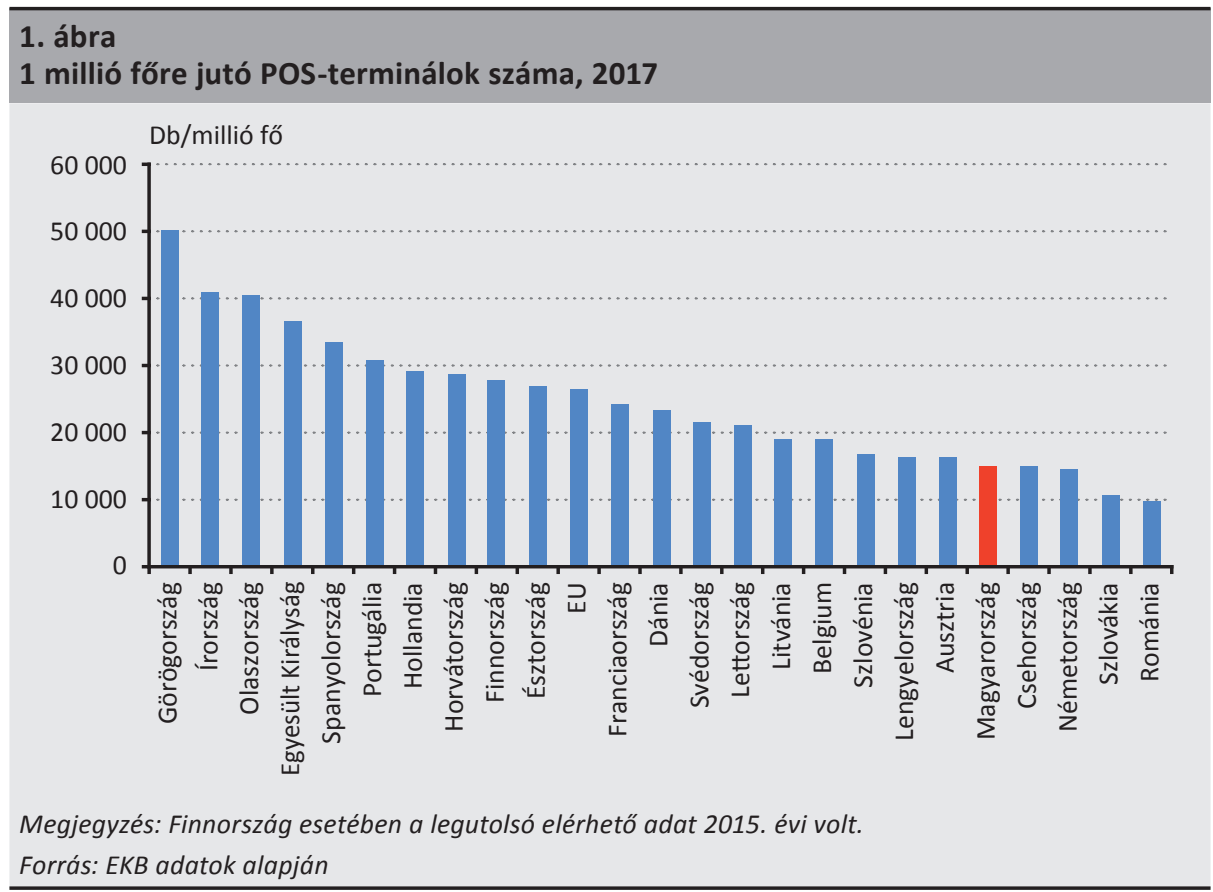

Az elmúlt évek jelentős fejlődése nagyban betudható az olyan központilag kezdeményezett és koordinált programoknak, mint az MNB kísérleti POS-terminál-telepítési programja, vagy a Pénzügyminisztérium országos POS-telepítési programjai ${ }^{1}$. A 2020. március 2-án az MNB irányításával Magyarországon is bevezetésre kerülő azonnali fizetés jelenthet számottevő előrelépést az elektronikus pénzforgalom terjedésében. Mivel az azonnali fizetési szolgáltatás gyakorlatilag bármilyen helyzetben alternatívát jelenthet majd a készpénzes fizetéseknek, ez akár a kiskereskedelmi vásárlásoknál és a szolgáltatások pénzügyi teljesítésénél biztosított elektronikus elfogadás jelentős bővülését is maga után vonhatja. Ehhez hozzájárulhatnak egyrészt a piaci szereplők, amelyek elfogadói szolgáltatásokat nyújthatnak a kereskedőknek, másrészt a további állami vagy jegybanki programok is nagyban támogathatják a fejlődést. Ugyanakkor hatékony fejlesztési tevékenység csak akkor valósítható meg, ha a szereplőknek pontos képe van a hazai pénzforgalomról. Ez egyúttal azt is jelenti, hogy a magyar pénzforgalom regionális jellemzőit is figyelembe kell venni.

Tanulmányunkkal ehhez a célhoz szeretnénk hozzájárulni, így bemutatni a hazai fizetési kártyás infrastruktúra és forgalom jelenlegi helyzetét területi szempontból. Írásunk újdonságát az adja, hogy a POS-hálózat és a kártyás forgalom, valamint az ebből származó pénzforgalmi szolgáltatói bevételek vizsgálatára korábban nem

${ }^{1}$ 47/2016. (XII. 6.) NGM-rendelet a bankkártya-elfogadó terminálok számának növeléséhez nyújtott támogatásról 
álltak rendelkezésre települési szintű adatok. Célunk egyrészt az, hogy ezen korábban nem elérhető adatok révén általános képet adjunk a hazai kártyarendszer területi jellemzőiről, továbbá hogy azonosítsuk azokat a tényezőket, amelyek hatással vannak a hazai kártyás fizetési mód fejlődésére, azaz az elfogadói hálózatra, a kártyabirtoklásra és a kártyás forgalomra, ezáltal segítve a hazai kártyarendszer további fejlődését. A felhasznált adatok ismertetése után így először az elfogadói, majd a kibocsátói oldal jellemzőit, fejlődésük főbb magyarázó tényezőit mutatjuk be, melyet a kártyás forgalmat taglaló fejezet követ. A tanulmány végén külön fejezetben foglaljuk össze a releváns konklúziókat.

\section{Felhasznált adatok és módszertan}

Elemzésünk elkészítésénél alapvetően három adatforrásra támaszkodtunk. A Gazdasági Versenyhivatal (GVH) ágazati vizsgálatot indított a bankkártya-elfogadás piacán, amelyhez településszintű adatokat kért be a kártyaelfogadói szolgáltatást nyújtó pénzforgalmi szolgáltatóktól a POS-terminálokra, az azokon lebonyolított forgalomról, valamint az azokból származó bevételekre vonatkozóan. Ezeket az adatokat az MNB belföldi jogsegélyszolgálat keretében kapta meg elemzési célokra. Az elfogadói hálózat adatai 2018. februári referencia-időpontra vonatkoznak, míg a forgalmi és bevételi adatok a 2013 első negyedévétől 2017 végéig terjedő időszakot ölelik fel. Annak érdekében, hogy ne csak az elfogadói oldal szempontjából vizsgáljuk a hazai pénzforgalmat, hanem a fogyasztók - azaz a számla- és kártyabirtokosok - oldaláról is, az MNB megbízásából a Központi Statisztikai Hivatal (KSH) által 2014-ben lebonyolított „Miből élünk” adatfelvétel régiószintű adatait vizsgáltuk, melyet részletesen bemutat Simon - Valentiny (2016) tanulmánya. Ezeket az adatforrásokat a KSH területi (megyei, települési) szintű (Tájékoztatási adatbázis; Fókuszban a megyék) adataival egészítettük ki.

Az adatok leíró jellegú vizsgálata mellett kutatási kérdéseinket lineáris regressziók, logisztikus regressziók és panelregressziók segítségével vizsgáltuk, mely modelleket a következő fejezetekben mutatjuk be részletesen. Területi részletezettségük miatt a GVH-adatok egyedülálló lehetőséget nyújtanak a hazai kártyarendszer részletes vizsgálatára, mivel az MNB rendszeres pénzforgalmi adatgyújtései csak országos szintű adatokat tartalmaznak. Ugyanakkor - ahogy azt az egyes részfejezetekben is jelezzük - a megfelelő bontású (településszintű, negyedéves) adatok a gazdaság és társadalom más területein rendkívül korlátozott körben állnak rendelkezésre, így a modellekbe építhető magyarázó változók szűk köre a modellekre is hatással lehet. 


\section{Kártyaelfogadói hálózat}

A kártyás elfogadói hálózat lefedettségét a POS-terminálok számával vizsgáltuk a GVH-adatok segítségével. Ez némileg eltér a kártyát elfogadó helyek (jellemzően kiskereskedői, valamint szállás- és vendéglátóhelyek) számától, mivel egy elfogadóhelyen több terminál is lehet, azonban megfelelően mutatja az elfogadói hálózat lefedettségi regionális eltéréseit. A várakozásoknak megfelelően megyei szinten Budapest lefedettsége kimagasló, az ezer főre jutó terminálok száma 26 darab, köszönhetően annak, hogy az összes terminál több mint harmada itt került kihelyezésre (2. ábra). Emellett Fejér és Pest megye mutat magasabb értékeket az ezer főre jutó terminálok tekintetében (utóbbi elsősorban a Budaörsöt is magába foglaló Budakeszi járás miatt, ahol nagymértékben koncentrálódnak az autópályák biztosította könnyű megközelíthetőség miatt a kiskereskedelmi egységek), míg Borsod-Abaúj-Zemplén, Nógrád és Szabolcs-Szatmár-Bereg megyékben a legrosszabb a helyzet ebből a szempontból, ahol az ezer főre jutó készülékek száma alig haladja meg a 7-et.

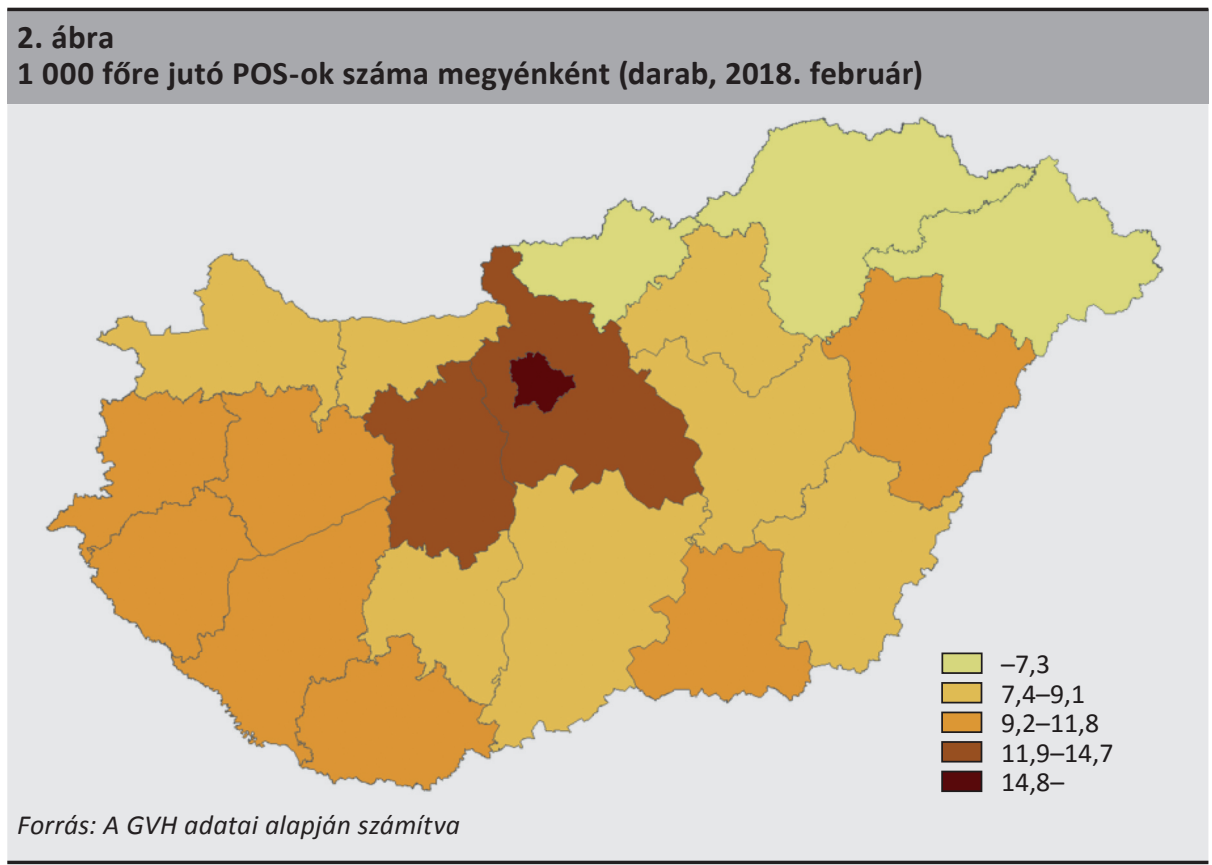

A képet tovább árnyalja, ha járási szintű adatokat is vizsgálunk (3. ábra). Eszerint számos alföldi járásban is alacsony a kártyás pénzforgalmi infrastruktúra fejlettsége. Vidéken a legmagasabb az agglomerációs térségekben, valamint a Balaton környékén, de a várakozásoknak megfelelően alapvetően a nagyvárosok térségében 
koncentrálódik a kártyás elfogadói infrastruktúra (2. ábra). Hasonló területi eltéréseket látunk akkor is, ha a POS-ok számát a térségben regisztrált vállalkozások számához viszonyítjuk. Megvizsgáltuk továbbá településtípus szerint is az ezer lakosra jutó POS-ok számát. A várakozásnak megfelelően a mutató értéke a legalacsonyabb a községekben $(4,9)$ és a nagyközségekben $(6,2)$, míg valamivel kedvezóbb, de a fővárositól még mindig elmaradó a városok $(10,2)$ és a megyei jogú városok $(19,3)$ terminálellátottsága.

\section{3. ábra \\ 1000 före jutó POS-ok száma járásonként (darab, 2018. február)}

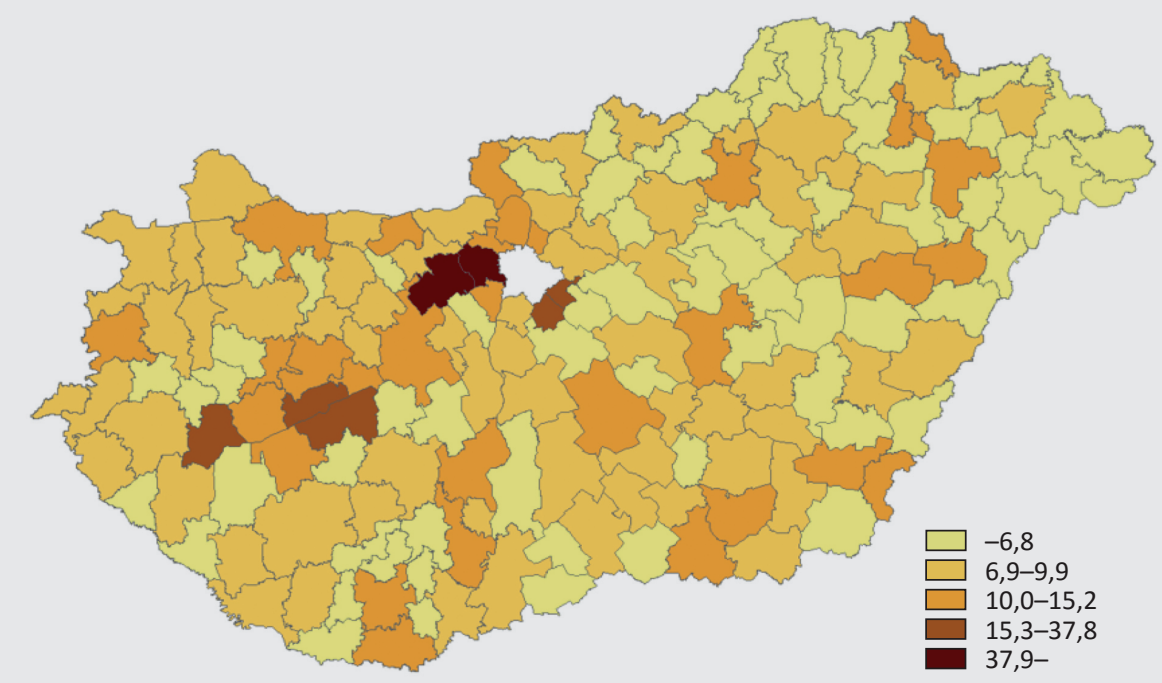

Forrás: A GVH adatai alapján számítva

A kártyaelfogadási hálózat fejlődését befolyásoló tényezőknek az azonosításához lineáris regresszióval vizsgáltuk, hogy mely változók hatnak szignifikáns mértékben e készülékek számára azokon a településeken, ahol találhatók POS-terminálok. A regresszióban az alábbi változókat vettük figyelembe:

$\log (\mathrm{POS})=\beta_{0}+\beta_{1}$ jogkód $+\beta_{2}$ régiókód $+\beta_{3}$ vállarány $+\beta_{4} \log ($ nép $)+\beta_{5} \log (\mathrm{bev})+\mu$, ahol

- a függő változó:

- $\log (P O S)$ : az adott településen található POS-terminálok darabszámának logaritmusa

- a magyarázó változók 
- jogkód: az adott település jogállása (Budapest és megyei jogú városok; városok; községek)

- régiókód

- vállarány: a szálláshely, vendéglátás, kereskedelem nemzetgazdasági ágban regisztrált vállalkozások aránya az összes regisztrált vállalkozáson belül

- log(nép): az adott település népességszámának logaritmusa

- log(bev): az adott településen található POS-terminálokból származó bevételek logaritmusa (azaz a készülékek jövedelmezősége - mennyire éri meg telepíteni őket)

\section{1. táblázat}

A kártyás elfogadói hálózat fejlettségét magyarázó regresszió becsült együtthatói, 2018. első negyedév

\begin{tabular}{|c|c|}
\hline Változók & POS-terminálok száma (logaritmus) \\
\hline \multicolumn{2}{|c|}{ Jogállás (Budapest és megyeszékhelyek) } \\
\hline Városok & $\begin{array}{l}-0,86 * \\
(-7,12)\end{array}$ \\
\hline Nagyközségek & $\begin{array}{c}-1,37^{*} \\
(-10,35)\end{array}$ \\
\hline Községek & $\begin{array}{c}-1,58^{*} \\
(-11,99)\end{array}$ \\
\hline \multicolumn{2}{|c|}{ Régiók (Közép-Magyarország Budapesttel együtt) } \\
\hline Közép-Dunántúl & $\begin{array}{l}-0,10 * \\
(-1,96)\end{array}$ \\
\hline Nyugat-Dunántúl & $\begin{array}{c}-0,09 \\
(-1,82)\end{array}$ \\
\hline Dél-Dunántúl & $\begin{array}{c}-0,04 \\
(-0,83)\end{array}$ \\
\hline Észak-Magyarország & $\begin{array}{l}-0,13^{*} \\
(-2.57)\end{array}$ \\
\hline Észak-Alföld & $\begin{array}{c}-0,03 \\
(-0,67)\end{array}$ \\
\hline Dél-Alföld & $\begin{array}{c}0,00 \\
(0,02)\end{array}$ \\
\hline Vállalkozások aránya & $\begin{array}{c}2,17 * \\
(12,82)\end{array}$ \\
\hline Népesség (logaritmus) & $\begin{array}{c}0,55^{*} \\
(29,76)\end{array}$ \\
\hline Bevételek (logaritmus) & $\begin{array}{c}0,20 * \\
(26,29)\end{array}$ \\
\hline Konstans & $\begin{array}{l}-1,70^{*} \\
(-7,60)\end{array}$ \\
\hline $\mathbf{R}^{2}$ & 0,86 \\
\hline $\mathbf{N}$ & 2254 \\
\hline \multicolumn{2}{|c|}{$\begin{array}{l}\text { Megjegyzés: * } 95 \text { százalékos konfidenciaszinten szignifikáns együtthatók, zárójelben a t-próbák értékei. } \\
\text { Forrás: A GVH és KSH adatai alapján számítva }\end{array}$} \\
\hline
\end{tabular}


Az 1. táblázatba foglalt eredmények azt mutatják, hogy a nagyvárosokhoz képest szignifikánsan alacsonyabb a terminálok száma a település méretének csökkenésével, azaz a kisebb településeken minden más változót kontrollálva az elfogadói hálózat kiterjedtsége is kisebb. Területi szempontból a legfejlettebb - jelen modellben Budapestet is magában foglaló - közép-magyarországi régióhoz képest Közép-Dunántúl és Észak-Magyarország esetében szignifikánsan alacsonyabb a terminállefedettség, ugyanakkor ennek mértéke csekély. A kiskereskedelmi és vendéglátóipari szektor vállalkozásainak növekvő részaránya az összes regisztrált vállalkozáson belül a kártyás elfogadói hálózat nagyságára is pozitív hatással van egy adott településen. Hasonlóképp pozitív kapcsolat és szignifikáns hatás merül fel a népességszámnál és a terminálokból származó bevételeknél. Azaz a népesség 1 százalékos emelkedése 0,55 százalékkal, míg a pénzforgalmi szolgáltatói bevételek 1 százalékos emelkedése 0,2 százalékkal növeli a POS-terminálok számát az adott településen. Megjegyzendő, hogy a településtípusra és a település nagyságára is kontrollálunk modellünkben, és ez is okozhatja a csekély mértékű regionális különbségeket. Korlátot jelent az elemzésben, hogy nem állnak rendelkezésre a kiskereskedelmi egységek településszintű adatai, így nem lehetett vizsgálni azt, hogy egy adott településen ezen egységek mekkora részében van kártyaelfogadás. Ez különösképp fontos abból a szempontból, hogy amennyiben nincs versenyhelyzet - azaz például egy kisebb településen csak egyetlen kiskereskedő van -, akkor kevésbé van rákényszerítve a kereskedő a kártyás fizetés biztosítására.

\section{Lakossági kártyabirtoklás}

A lakosság kártyaellátottságát, azaz a kártyakibocsátói oldali jellemzőket a „Miből élünk" adatfelvétel első hullámának adatai alapján vizsgáltuk. A 72,5 százalékos kártyalefedettség összhangban van Ilyés - Varga (2015) országos szintű eredményeivel csakúgy, mint a kártyabirtoklás életkor szerinti eloszlása (4. ábra). Ez alapján elmondható, hogy az idősebb korosztályok esetében jelentős mértékben csökken a kártyabirtoklás aránya. A háztartásfő iskolai végzettsége szerinti bontás esetében is számottevő különbségeket találunk: míg az alapfokú végzettségűek kevesebb mint felének van bankkártyája, addig a közép- és felsőfokú végzettséggel rendelkezőknél ugyanez az arány 72, ill. 85 százalék. A háztartásfő gazdasági aktivitása szerint vizsgálva a lefedettséget, legmagasabb (79 százalékos) érték az alkalmazottaknál tapasztalható, melytől némileg elmarad a diákok és háztartásbeliek 75 százalék körüli aránya, a nyugdíjas vagy munkanélküli személyeknél pedig jóval alacsonyabb (60 százalék körüli) ez az érték. A diákok esetében számottevő a 25 év körüliek aránya, akik nem feltétlenül egyetemi képzésben vesznek részt, ez magyarázhatja azt, hogy míg a 20 év alattiak esetében 90 százalék körüli a lefedettség, addig a diákok csoportját tekintve alacsonyabb. 


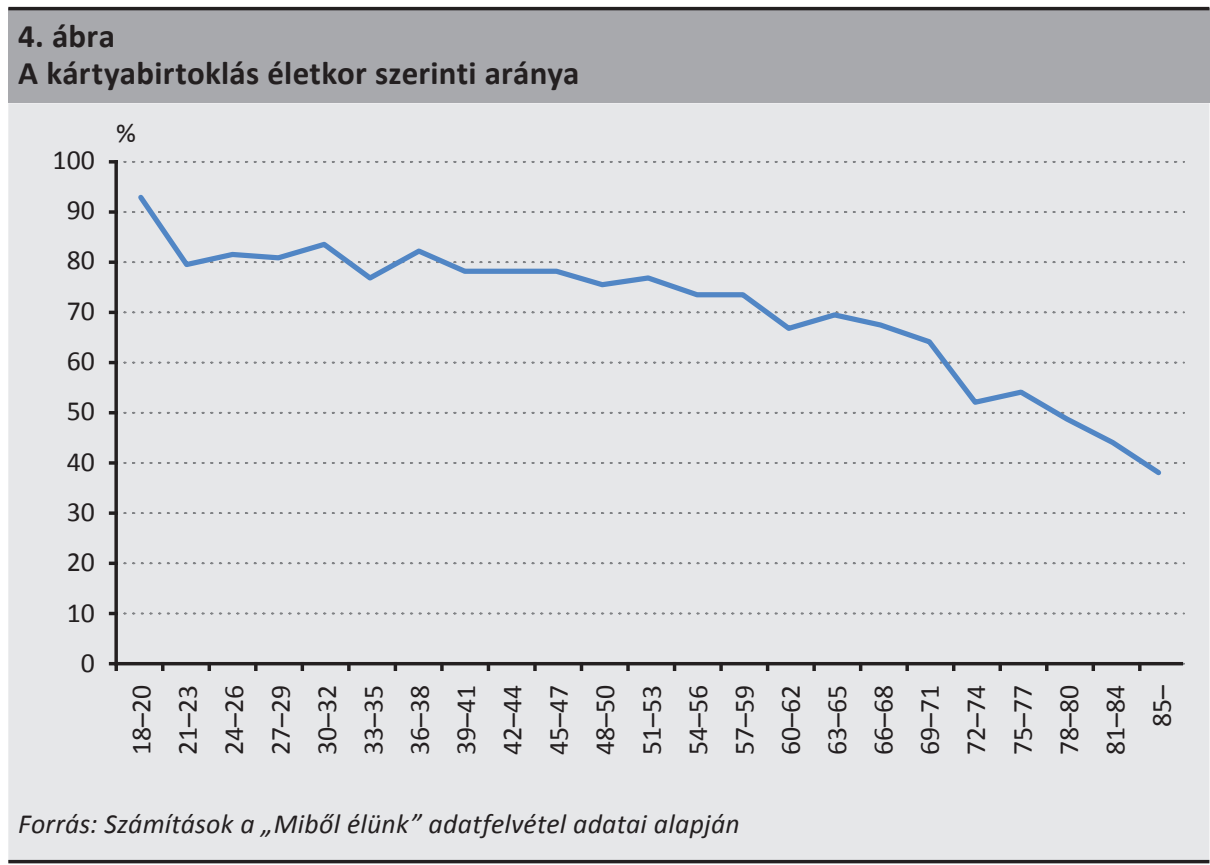

Látható ugyanakkor, hogy regionális szinten is jelentős eltérések adódnak ezen a téren, legrosszabb képet az alföldi régiók mutatnak, míg legkedvezőbb a helyzet Közép-Magyarországon, ez alapján a kártyával való ellátottságban közel 20 százalékpontos különbség mutatkozik a legfejlettebb és a legrosszabb helyzetben lévő régió között (2. táblázat).

\section{2. táblázat}

A magyar háztartások számla- és kártyaellátottsága regionális bontásban, 2014

\begin{tabular}{c|c} 
Régió & Kártyalefedettség (\%)* \\
\hline Közép-Magyarország** & 80,3 \\
\hline Közép-Dunántúl & 71,8 \\
\hline Nyugat-Dunántúl & 75,0 \\
\hline Dél-Dunántúl & 70,7 \\
\hline Észak-Magyarország & 72,0 \\
\hline Észak-Alföld & 61,0 \\
\hline Dél-Alföld & 68,1 \\
\hline Országos átlag & 72,5 \\
\hline
\end{tabular}

Megjegyzés: * Lefedettség: a háztartás legalább egy tagja rendelkezik számlával vagy fizetési kártyával,

** Budapest adatait a közép-magyarországi adatok között vettük figyelembe.

Forrás: Számítások a „Miböl élünk” adatfelvétel adatai alapján 
A háztartások fizetési kártyával való ellátottságát logisztikus regresszió segítségével is vizsgáltuk, annak érdekében, hogy a lefedettséget befolyásoló tényezőket azonosítani tudjuk. A regresszió függő változójának értéke 1 , ha van és 0 , ha nincs az adott háztartásban bankkártya. A regresszióban magyarázó változóként szerepelnek területi jellemzők, a háztartás jövedelmi és szociális helyzetét leíró változók, valamint a háztartásfő jellemzői is. Ahogy az a 4. ábrán is látszik, a háztartásfők esetében 60 éves kor felett némileg meredekebben csökken a kártyabirtoklás aránya, ezért korcsoportokat alkalmaztunk, hogy ezt a nem teljesen lineáris hatást kezelni tudjuk. A 3. táblázatban a logisztikus regresszió esélyhányadosait mutatjuk be, amely alapján amennyiben az adott magyarázó változó esélyhányadosa 1 alatt van, akkor csökkenti, ha 1 fölött van, akkor növeli a kártyabirtoklás valószínűségét. Modellünkben mindegyik magyarázó változó esetében szignifikáns hatás mutatkozott a vizsgált 95 százalékos konfidenciaszinten. A logisztikus regresszió a következőképp néz ki:

$y=\beta_{0}+\beta_{1}$ régiókód $+\beta_{2}$ települestípus $+\beta_{3}$ jövedelem $+\beta_{4}$ szocjuttatás

$+\beta_{5} \log ($ fogyasztás $)+\beta_{6}$ élelmiszerfogyasztás $+\beta_{7}$ rezsiköltség+ $\beta_{8}$ vállalkozás

$+\beta_{9}$ nem $+\beta_{10}$ kor $+\beta_{11}$ végzettség $+\beta_{12}$ gazdaktivitás $+\mu$,

ahol

- a függő változó:

- y: Van-e a vizsgált háztartás tulajdonában bankkártya (0 vagy 1)

- a magyarázó változók:

- régiókód

- településtípus: az adott település típusa (Budapest, megyeszékhely, város, község)

- jövedelem: egy före jutó éves háztartási jövedelem (3 millió Ft alatt, 3-5 millió Ft között, 5 millió Ft felett)

- szocjuttatás: szociális juttatás az elmúlt 12 hónapban (igen, nem)

- log(fogyasztás): összes fogyasztási kiadás logaritmusa

- élelmiszerfogyasztás: élelmiszerfogyasztás aránya az összes kiadáson belül

- rezsiköltség: rezsiköltségek aránya az összes kiadáson belül

- vállalkozás: van-e egyéni vagy társas vállalkozásuk, vállalatuk? (van, nincs)

- nem: férfi, nő

- kor: 0-29, 30-39, 40-49, 50-59, 60 év fölött

- végzettség: alapfokú, középfokú, felsőfokú

- gazdaktivitás: munkanélküli, diák, nyugdíjas, egyéb (GYES, GYED, betegállomány, háztartásbeli, rokkant) 


\begin{tabular}{|c|c|}
\hline $\begin{array}{l}\text { 3. táblázat } \\
\text { A háztartások kártyalefedettségét befolyásoló tényez }\end{array}$ & \\
\hline Változó & Kártyabirtoklás \\
\hline Régiók (Közép-Magyarország) & \\
\hline Közép-Dunántúl & $0,73^{*}$ \\
\hline Nyugat-Dunántúl & $0,85^{*}$ \\
\hline Dél-Dunántúl & $0,79 *$ \\
\hline Észak-Magyarország & $0,78^{*}$ \\
\hline Észak-Alföld & $0,52 *$ \\
\hline Dél-Alföld & $0,75^{*}$ \\
\hline Településtípus (Budapest) & \\
\hline Megyeszékhely & $1,39 *$ \\
\hline Város & $0,88^{*}$ \\
\hline Község & $0,90 *$ \\
\hline Jövedelmi és szociális helyzet & \\
\hline 1 före jutó összes éves háztartási jövedelem (3 millió Ft alatt) & \\
\hline 3-5 millió Ft között & $1,06^{*}$ \\
\hline 5 millió Ft felett & $1,46^{*}$ \\
\hline Szociális juttatás az elmúlt 12 hónapban (Igen) & $0,75^{*}$ \\
\hline Összes fogyasztási kiadás (Ft) (logaritmus) & $1,71 *$ \\
\hline Élelmiszerfogyasztás aránya az összes kiadáson belül & $1,20 *$ \\
\hline Rezsiköltségek aránya az összes kiadáson belül & $1,37^{*}$ \\
\hline Van-e egyéni vagy társas vállalkozásuk, vállalatuk? (Nincs) & $0,74 *$ \\
\hline Háztartásfő jellemzői & \\
\hline Nem (nő) & $1,05^{*}$ \\
\hline Kor (0-29 év) & \\
\hline 30-39 év & $0,90^{*}$ \\
\hline 40-49 év & $1,11^{*}$ \\
\hline 50-59 év & $0,92^{*}$ \\
\hline 60 év fölött & $0,50 *$ \\
\hline Iskolai végzettség (alapfokú) & \\
\hline Középfokú & $2,04^{*}$ \\
\hline Felsőfokú & $3,53^{*}$ \\
\hline Gazdasági aktivitás (Alkalmazott) & \\
\hline Munkanélküli & $0,78^{*}$ \\
\hline Diák & $4,31 *$ \\
\hline Nyugdíjas & $0,96 *$ \\
\hline Egyéb (GYES, GYED, betegállomány, háztartásbeli, rokkant) & $0,66^{*}$ \\
\hline Konstans & $0,22 *$ \\
\hline $\mathrm{N}$ & 6049 \\
\hline $\begin{array}{l}\text { Megjegyzés: * } 95 \text { százalékos konfidenciaszinten szignifikáns. } \\
\text { Forrás: Számítások a „Miből élünk” adatfelvétel adatai alapján }\end{array}$ & \\
\hline
\end{tabular}


Területi szempontból minden régió esetében alacsonyabb a kártyabirtoklás valószínúsége a közép-magyarországihoz képest, a legrosszabb a helyzet Észak-Alföldön, megerősítve a leíró adatokat. Kuttor - Pál (2019) vizsgálta a banki fiókhálózat regionális eloszlását. Eredményei alapján a kártyabirtoklás és a fiókhálózat eloszlása hasonló képet mutat, ezt a későbbiekben érdemes lehet vizsgálni. A településtípusok esetében Budapesthez viszonyítva a megyeszékhelyeken szignifikánsan több, míg az egyéb városokban és a községekben alacsonyabb a kártyabirtoklás valószínúsége. Ez összefüggésben lehet azzal, hogy ezen településtípusok esetében jellemzően fejletlenebb a pénzforgalmi infrastruktúra is, ahogy azt az előző fejezetben is láttuk, azaz a kártyákat kevesebb helyen lehet használni, ami a birtoklásra is negatív hatással van. A háztartás egy före jutó jövedelménél kategóriákat alkalmaztunk, ez alapján az látható, hogy a jövedelem növekedésével nő a kártyabirtoklás valószínúsége. Emellett az eredmények azt mutatják, hogy a szociális juttatásokban (pl. családi pótlék, GYED, GYES, segélyek, járadékok) részesülő háztartások esetében némileg alacsonyabb a kártyabirtoklás. Fogyasztási szempontból szintén az mondható el, hogy a jobb anyagi helyzetű háztartásoknál magasabb a kártyalefedettség és ez a megállapítás akkor is igaz, ha az élelmiszerre és a rezsire költött összegek teljes fogyasztáson belüli arányát nézzük. A háztartásfő neme rendkívül kis mértékben befolyásolja csak a kártyabirtoklást háztartási szinten, a nő háztartásfők esetén kicsivel magasabb ez az arány. A kor szempontjából a fiatal, 30 év alatti felnőttekhez képest a 40-49 év közötti korcsoport kivételével minden más korosztályban alacsonyabb a kártyabirtoklás valószínűsége, különösen a nyugdíjas korosztály esetében alacsony a kártyalefedettség. Ez összhangban van Ilyés - Varga (2015) személyi szintű kérdőívekre vonatkozó eredményeivel, amely a legerőteljesebb csökkenést a kártyaellátottság terén szintén a 60 év feletti korosztálynál mutatta. Hasonlóak az eredmények az iskolai végzettség hatására vonatkozóan is, azaz a felsőfokú végzettséggel rendelkezők esetében szignifikánsan magasabb a kártyabirtoklás (a modell alapján a legjelentősebb hatás ennél a változónál jelentkezik), megerősítve a korábbi kutatás következtetéseit. Ezzel összhangban van az is, hogy Végső et al. (2018) szerint a készpénzes fizetés és az iskolai végzettség foka között negatív kapcsolat figyelhető meg. A GYES-en, betegállományban lévők, rokkantak, munkanélküliek és nyugdíjasok esetében szignifikánsan alacsonyabb a kártyabirtoklás valószínűsége az alkalmazottakhoz képest, a diákok esetében pedig magasabb. Ez utóbbi feltehetően annak tudható be, hogy ez a korosztály jobban preferálja a készpénzhez képest az elektronikus fizetési módok használatát. Továbbá a 18 év feletti diákok nagy része már a felsőoktatásban tanul, ahol nélkülözhetetlen a bankszámla és bankkártya, ez szintén magyarázhatja a kiemelkedően magas kártyabirtoklási eredményt. 


\section{Kártyahasználat}

A kártyás forgalom területi eloszlását egyrészt az egy POS-terminálra jutó forgalommal érdemes vizsgálni, ilyen módon figyelembe véve az elfogadói infrastruktúra térbeli eltéréseit, azaz alapvetően azt vizsgálva, hogy a kártyabirtokosok mennyire használják intenzíven a kiépített kártyaelfogadói hálózatot. Darabszám szerinti adatok nem állnak rendelkezésre, csak értékbeniek, ami a területi összevetést némileg torzítja. A kártyás fizetési mód ugyanis elsősorban a kiskereskedelemben és szolgáltatásnyújtásban elterjedt, melyek árszínvonalában lehetnek eltérések járásonként (5. ábra). A leíró adatok alapján mindenesetre elmondható, hogy a forgalom területi eloszlása jóval koncentráltabb az elfogadói hálózaténál, és a nagyvárosok mellett elsősorban az ország északnyugati negyedében tapasztalható intenzív kártyahasználat, ami betudható többek között a budapesti agglomeráció gazdasági fejlettségének, a Balaton-felvidéki turizmusnak, valamint a nyugati határhoz közeli ipari központoknak. A keleti határ melletti területeken ugyanakkor a POS-hálózat viszonylagos fejlettsége ellenére is alacsony a forgalom. ${ }^{2}$

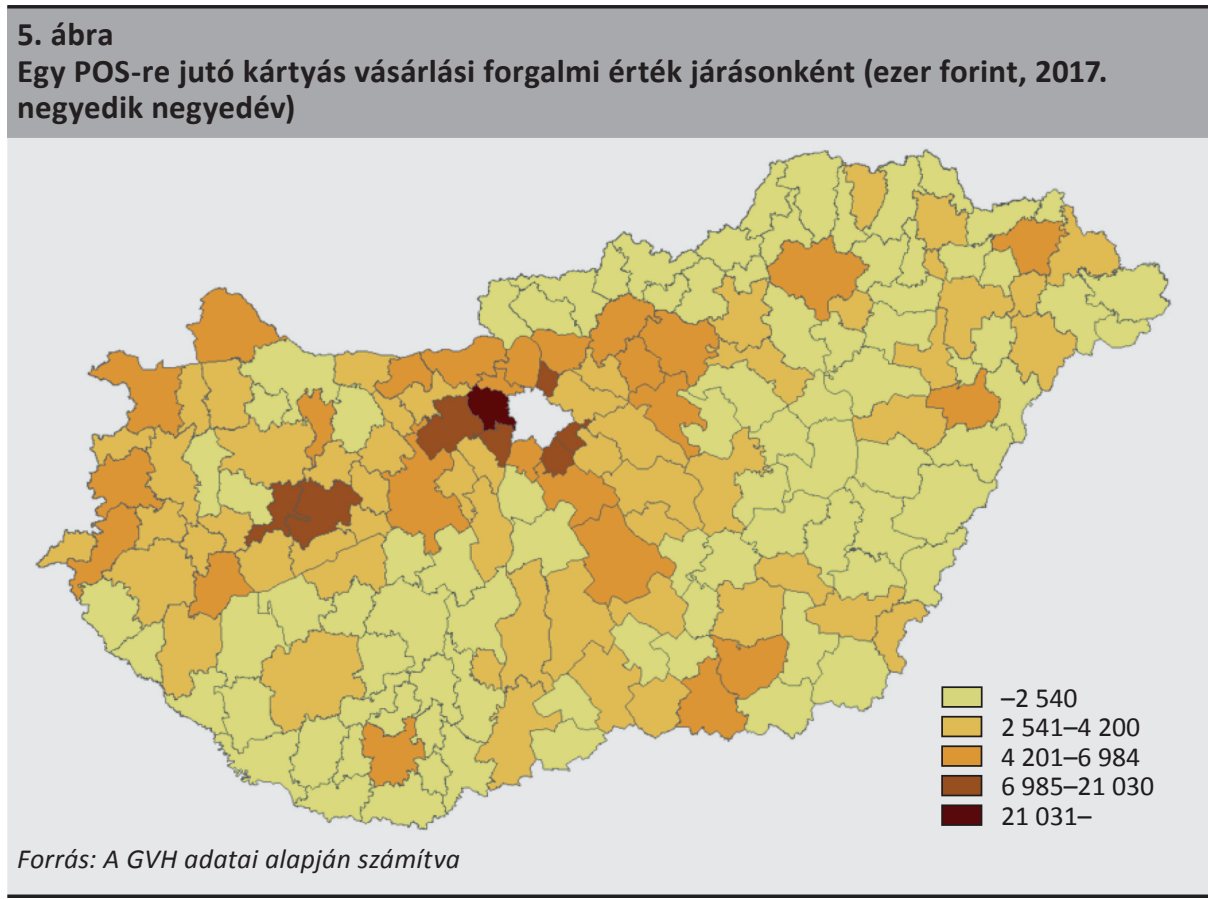

${ }^{2} \mathrm{~A}$ budaörsi járás kimagasló értékét a fővárosba vezető autópályák mellé települt kiskereskedelmi áruházak jelentős forgalma magyarázhatja, míg a bicskei járás esetében az adatok torzítása feltételezhető az egyik nagy kiskereskedelmi lánc központja miatt. 
Fontos látni, hogy a kártyás forgalmat számos tényező befolyásolja, így többek között az adott területen a kiskereskedelmi és vendéglátó szektor nagysága, vagy az elfogadói hálózat kiépítettsége. Lényeges ugyanakkor a kártyabirtokosi (kibocsátói) oldal szerepe is, azaz hogy mekkora a lakosság körében a kártyabirtoklás aránya (ezt az előző fejezetben mutattuk be), ill. a kártyabirtokosok mennyire intenzíven használják fizetésre a meglévő kártyáikat. Erről nyújthat átfogó képet, ha a kártyás forgalmat az adott terület lakosságához viszonyítjuk (6. ábra). Ebből az látszik, hogy a kártyás fizetési módot intenzívebben használják a nagyvárosokban élők (ami persze szintén összefügghet az elfogadói oldal fejlettségével).

\section{6. ábra \\ Egy före jutó kártyás vásárlási forgalom járásonként (ezer forint, 2017. negyedik negyedév)}

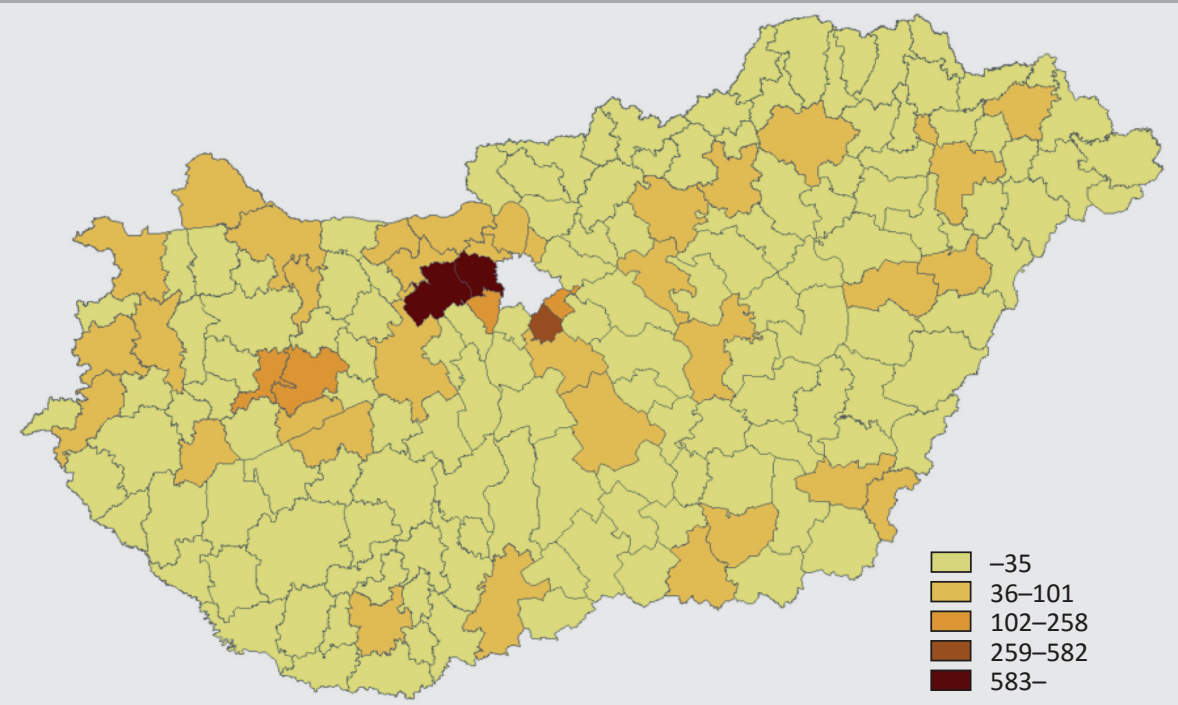

Forrás: A GVH adatai alapján számítva

A kihelyezett POS-terminálok jövedelmezőségét, azaz azt vizsgálva, hogy egy terminálra mekkora pénzforgalmi szolgáltatói bevétel (azaz kereskedői szempontból költség) jut, hasonlót kapunk (7. ábra). Ez fóleg azzal van összefüggésben, hogy a pénzforgalmi szolgáltatói díjak jelentős része értékarányos, azaz ha magas a forgalom, magas a bevétel is. A forgalmi adatokkal is kontrollálva - leosztva - a bevételi adatokat elmondható, hogy a kártyás infrastruktúra szempontjából kevésbé fejlett kelet-magyarországi és dél-dunántúli területeken általánosságban jóval drágább a kereskedők számára a kártyaelfogadás biztosítása. Ennek oka ugyanakkor feltehetően elsősorban nem a pénzforgalmi szolgáltatók eltérő árazása, hanem az, hogy ezeken a területeken más a kiskereskedői szektor szerkezete, azaz a jobb alkupozícióban lévő, ezáltal olcsóbb kártyaelfogadói szolgáltatást igénybe vevő nagyobb keres- 
kedők aránya alacsonyabb, továbbá a kisebb kereskedők esetében az alacsonyabb forgalom miatt a pénzforgalmi szolgáltatók költségeinek megtérülése is lassabb.

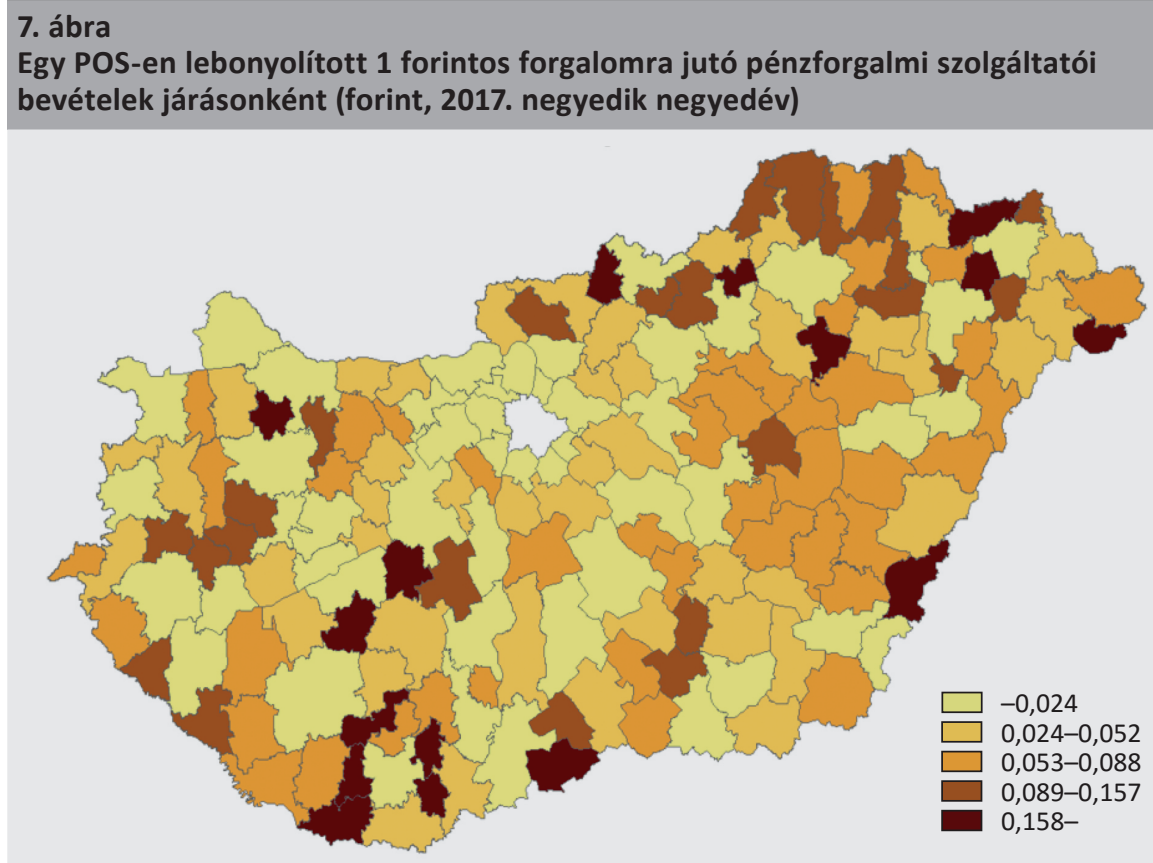

Forrás: A GVH adatai alapján számítva

A kártyahasználatot befolyásoló tényezőket több módszerrel is vizsgáltuk, mivel úgy, ahogy az elfogadói hálózat elemzésénél, a forgalom esetében is problémát jelent a települési szinten rendelkezésre álló magyarázó változók korlátozott köre. A kártyás forgalom alakulásában alapvetően három fő tényező játszhat szerepet:

- Az elfogadói hálózat fejlettsége: Van-e kellő számú terminál, hogy aki szeretne, az tudjon kártyával fizetni. (Ennek az oldalnak a jellemzőivel az első fejezetben foglalkoztunk.)

- A kártyakibocsátói, azaz a kártyabirtokosi oldal jellemzői: Hány és milyen szociodemográfiai összetételű vásárló merülhet fel potenciális kártyahasználóként; mekkora a kártyabirtoklási arány a lakosság körében, továbbá a vásárlói preferenciák. (Ennek az oldalnak a jellemzőivel a 2. fejezetben foglalkoztunk.) Végső és szerzőtársai (2018) tanulmányukban azt vizsgálták, hogy mi alapján döntenek a vásárlók az elektronikus, illetve a készpénzes fizetés mellett. Ezek alapján érdemes lehet további elemzéseket végezni. Eredményeik további támpontot nyújthatnak a kártyaelfogadás bővítését célzó intézkedéseknek, akár térségenként is. 
A tanulmány alapján nemcsak az elfogadói hálózat bővítésével, hanem egyéb népszerúsítő intézkedésekkel is lehet növelni a kártyás, illetve elektronikus fizetés volumenét, ez főleg a 2020. március 2-án induló azonnali fizetés esetén lehet különösen hatékony.

- A térség általános gazdasági fejlettsége, jellege: Hogyan alakul a kiskereskedelmi forgalom, mekkora szerepe van a térség gazdaságában a kártyaelfogadásban leginkább felmerülő kiskereskedelmi és vendéglátó szektornak (mekkora a turizmus szerepe). Modelljeink korlátja, hogy a kiskereskedelmi forgalom egészének alakulására vonatkozó adatok nem álltak rendelkezésre a szükséges részletezettségben, ezért ezt a tényezőt nem tudtuk beépíteni.

Elsőként 2018 első negyedévére vonatkozóan lineáris regresszióval vizsgáltuk a települési szintű kártyás forgalmat, mivel a POS-hálózatra vonatkozó adatok csak egy időpontra (2018. február) állnak rendelkezésre. Az elfogadói hálózatra vonatkozó adatok mellett a KSH települési szintű adatait használtuk fel. A következő modellt vizsgáltuk, amelyből már kivettük a nem szignifikáns hatású magyarázó változókat ${ }^{3}$ :

$$
\begin{aligned}
\log (\text { forg })= & \beta_{0}+\beta_{1} \log (\mathrm{POS})+\beta_{2} \log (\text { net })+\beta_{3} \text { vállarány }+\beta_{4} \text { jogkód } \\
& +\beta_{5} \text { munkanelkarány }+\mu,
\end{aligned}
$$

ahol

- a függő változó:

log(forg): a teljes kártyás forgalom (érték) logaritmusa az adott településen

- a magyarázó változók

- elfogadói hálózat jellemzői log(POS): a POS-terminálok számának logaritmusa az adott településen

- általános gazdasági fejlettséget jellemző mutatók: $\log (n e t)$ : internet-előfizetések számának logaritmusa az adott településen vállarány: a szálláshely, vendéglátás, kereskedelem nemzetgazdasági ágban regisztrált vállalkozások aránya az összes regisztrált vállalkozáson belül

- területi jellemzők: jogkód: az adott település jogállása (Budapest és megyei jogú városok; városok; községek)

- kártyabirtokosi oldal jellemzői: munkanelkarány: a munkanélküliek aránya (a 15-64 év közötti népességhez viszonyítva) az adott településen

\footnotetext{
${ }^{3}$ Nem volt szignifikáns például a régiós változó hatása vagy a 65 éven felüliek aránya a teljes népességen belül.
} 


\begin{tabular}{|c|c|}
\hline \multicolumn{2}{|c|}{$\begin{array}{l}\text { 4. táblázat } \\
\text { A kártyás forgalmat magyarázó regresszió }\end{array}$} \\
\hline Változók & Kártyás forgalmi érték (logaritmus) \\
\hline POS-terminálok száma (logaritmus) & $\begin{array}{l}1,62^{*} \\
(2,57) \\
\end{array}$ \\
\hline $\begin{array}{l}\text { Internet-előfizetések aránya a teljes } \\
\text { népességen belül }\end{array}$ & $\begin{array}{l}6,23^{*} \\
(8,45) \\
\end{array}$ \\
\hline Vállalkozások aránya & $\begin{array}{l}20,60^{*} \\
(12,14)\end{array}$ \\
\hline \multicolumn{2}{|l|}{ Jogállás (Bp. és megyeszékhelyek) } \\
\hline Városok & $\begin{array}{l}0,92^{*} \\
(2,34)\end{array}$ \\
\hline Községek & $\begin{array}{c}0,41 \\
(0,96)\end{array}$ \\
\hline Munkanélküliek aránya & $\begin{array}{l}-7,20^{*} \\
(-7,15)\end{array}$ \\
\hline Konstans & $\begin{array}{c}-2,67 * \\
(3,98) \\
\end{array}$ \\
\hline $\mathbf{R}^{2}$ & 0,62 \\
\hline $\mathbf{N}$ & 2260 \\
\hline
\end{tabular}

Az eredmények alapján elmondható, hogy a fejlettebb elfogadói hálózat valóban szignifikáns mértékben járul hozzá a kártyás forgalom bővüléséhez, azaz érdemes támogatni az infrastruktúra fejlettségét a készpénzhasználat visszaszorítása érdekében. Az infrastruktúra szempontjából pozitív hatása van az internetes lefedettség növelésének is, bár ez inkább általános gazdasági fejlettségi mutatóként értelmezhető jelen modellben. Mind az elfogadói hálózatnak, mind egy térség általános gazdasági helyzetének hatását mutatja az, hogy minél magasabb a kiskereskedelmi és a szálláshely és vendéglátás szektorokban regisztrált vállalkozások aránya, annál jelentősebb a kártyahasználat. A nagyvárosokhoz képest a városokban és a községekben alacsonyabbnak mutatkozik a kártyahasználat, összhangban a korábbiakban bemutatott leíró eredményekkel (4-5. ábrák), valamint Ilyés - Varga (2015) és Végső et al. (2018) tanulmányaival. A kártyabirtokosi oldalt tekintve a munkanélküliek arányának növekedése negatívan befolyásolja a kártyás forgalmat, ami összhangban van azzal a 4. fejezetben bemutatott eredményünkkel, hogy a szociálisan hátrányosabb helyzetben élők esetében a kártyabirtoklás is alacsonyabb.

A lineáris regressziók mellett panelregresszió alkalmazásával is vizsgáltuk a kártyás forgalmat befolyásoló tényezőket, mivel a forgalmi adatok 2013 első negyedévétől 2017 utolsó negyedévéig, azaz összesen 20 időszakra állnak rendelkezésre. A panelregressziókat megyei szinten futtattuk, mivel ezen a területi szinten a magyarázó változóknak szélesebb köre áll rendelkezésre, mint a településeknél. A magyarázó 
változók köre a lineáris regressziónál (4. táblázat) alkalmazottakhoz képest kiegészült (a függő változó, azaz a kártyás forgalom logaritmusának változatlansága mellett) a nyilvántartott álláskeresők végzettség szerinti hatásának vizsgálatával, azaz azzal, hogy az összes álláskeresőn belül mekkora volt az alap-, a közép- és a felsőfokú végzettségúek aránya.

5. táblázat

A megyei szintű panelregressziók eredménye, 2013 I. negyedév - 2017. IV. negyedév

\begin{tabular}{l|c}
\multicolumn{1}{c|}{ Változók } & Kártyás forgalom (logaritmus) \\
\hline Alkalmazottak aránya a teljes népességben & $6,06^{*}$ \\
& $(6,06)$ \\
\hline Havi nettó átlagkereset (logaritmus) & $1,46^{*}$ \\
& $(12,87)$ \\
\hline Munkanélküliek aránya a teljes népességben & $-6,81^{*}$ \\
\hline Vendégéjszakák száma kereskedelmi & $(-5,99)$ \\
\hline szálláshelyeken (logaritmus) & $0,16^{*}$ \\
\hline Konstans & $(9,69)$ \\
\hline$R^{2}$ & $-4,32^{*}$ \\
\hline
\end{tabular}

Megjegyzés: * 95 százalékos konfidenciaszinten szignifikáns együtthatók, zárójelben a t-próbák értékei Forrás: A GVH és KSH adatai alapján számítva

A panelelemzésben kapott eredmények (5. táblázat) megerősítik a keresztmetszeti elemzésünk következtetéseit, azaz hogy egy terület munkaerőpiaci viszonyai számottevően befolyásolják a kártyás forgalom alakulását. Emellett a jövedelmek és a vendégéjszakák esetében mutatkozott szignifikáns, pozitív kapcsolat, azaz a magasabb bérszínvonal és nagyobb vendégforgalom növeli a kártyás fizetési forgalmat is.

\section{Klaszterelemzés}

A klaszter- vagy csoportelemzés lényege, hogy a rendelkezésre álló változók alapján csoportosítja az adatokat, és ezzel többletinformációhoz juthatunk. Az algoritmus azokat a településeket sorolja egy csoportba, amelyek az adott adatok alapján ugyanahhoz a középponthoz vannak a legközelebb. Jelen esetben a kártyás forgalom és a POS-terminál száma alapján szeretnénk bővebb információt kapni arról, hogy a települések hogyan csoportosíthatók a kártyás fizetési mód jellemzői alapján. A klaszterelemzést elvégeztük 2-6 csoportra is, ezek alapján az optimális klaszterszám 4, a továbbiakban ennek a vizsgálatnak az eredményeit fogjuk bemutatni. Egyes települések tulajdonságai jelentősen eltérnek a többitől - kiugró értékként viselkednek - ezeket kihagytuk az elemzésből. Ilyen volt például Budapest, illetve a nulla POS-terminállal rendelkező települések. A maradék települések 4, jól elkülöníthető csoportba sorolhatók. 
A K-középpontú klaszterelemzés 4 stabil, jól elkülöníthető klaszterre bontja a kilógó értékek kezelése után maradt 2439 adatot (települést). A négy klaszterből a legkisebb elemszámú nagymértékben elhatárolódik a többi csoporttól, ez a 8 elemszámú csoport még kevesebb klaszterre is elkülönül a többi adattól. Ez a 4. csoport tartalmazza a legnagyobb városokat: Székesfehérvár, Debrecen, Nyíregyháza, Győr, Pécs, Kecskemét, Miskolc, Szeged. Ezt a csoportot a viszonylag magas kártyás forgalom mellett rendkívül széleskörű elfogadói hálózat jellemzi. Kuttor - Pál (2019) tanulmányában 2017-es adatokat vizsgálva jutott hasonló következtetésre. A tanulmányban összforgalom alapján készített csoportosítás alapján szintén ez a nyolc megyeszékhely emelkedett ki a vizsgált települések közül. A 3. csoportot szintén magas forgalom jellemzi, azonban a 4. csoporténál jelentősen alacsonyabb (átlagosan 585 körüli) POS-terminál-szám mellett, ebbe a csoportba tartoznak az előző csoportból kimaradt megyeszékhelyek, illetve nagyobb, fejlettebb városok ${ }^{4}$. $A z$ 1. csoport tartalmazza az előző két csoportból kimaradt, kevésbé fejlett nagyobb városokat és a fejlett közepes városokat. Ezt a csoportot közepes POS-terminál-szám (163 körüli érték) és -forgalom jellemzi. A kisvárosokat és legkisebb településeket tartalmazó 2. csoport szintén jól elkülöníthető. Mivel a 0 POS-terminállal rendelkező településeket előzetesen kiszűrtük, ezért ebbe a csoportba azok a kistelepülések kerültek, ahol van POS-terminál, azonban ezek száma viszonylag alacsony (átlagosan 9 körül van a csoportban), illetve a forgalom is lényegesen alacsonyabb a többi csoporthoz képest (6. táblázat).

\section{6. táblázat}

A kártyás fizetési mód jellemzői alapján képzett települési klaszterek

\begin{tabular}{c|c|c|c} 
Klaszterszám & Csoport elemszáma & $\begin{array}{c}\text { Kihelyezett POS- } \\
\text { terminálok száma }\end{array}$ & $\begin{array}{c}\text { Kártyás forgalom } \\
\text { logaritmusa }\end{array}$ \\
\hline $\mathbf{1}$ & 118 & 163,5 & 14,4 \\
\hline $\mathbf{2}$ & 2284 & 9,5 & 8,7 \\
\hline $\mathbf{3}$ & 29 & 585,8 & 16,2 \\
\hline $\mathbf{4}$ & $\mathbf{8}$ & 1852,6 & 17,6 \\
\hline
\end{tabular}

Forrás: A GVH adatai alapján számítva

A vizsgálat alapján elmondható, hogy a kiválasztott változók szerint a települések jól elkülöníthető csoportokba sorolhatók. Az azonos méretű és fejlettségű települések azonos csoportba kerültek a POS-terminál-szám és a kártyás forgalom alapján, ami azt jelenti, hogy ezeken az egy klaszterbe tartozó településeken közel azonos menynyiségű POS-terminál található, és a kártyás forgalom is hasonló. A klaszterek jól elkülöníthetők, azaz a különböző csoportba tartozó települések eltérők a vizsgált változók alapján (Melléklet 8. ábra). A fent bemutatott megközelítés mellett érdemes

${ }^{4}$ Szombathely, Veszprém, Szolnok, Eger, Békéscsaba, Siófok, Kaposvár, Sopron, Zalaegerszeg, Tatabánya, Budaörs, Üllő, Érd, Dunakeszi, Gödöllő, Pápa, Ajka, Dunaújváros, Nagykanizsa, Szekszárd, Gyöngyös, Salgótarján, Hajdúszoboszló, Gyula, Baja, Hódmezővásárhely 
lehet arányosított változók alapján is klaszterelemzést végezni, mivel így a kisebb, de fejlettebb településeket is könnyebben tudjuk azonosítani. A POS-terminállal nem rendelkező településeket jelen esetben is kiszűrtük. Ennél a megközelítésnél a következő változókra készítettünk 4 központú klaszterelemzést: 1000 főre jutó POS-terminálok száma, 1 főre jutó kártyás forgalom és 1 POS-terminálra jutó forgalom. Ekkor két kis elemszámú, egy közepes elemszámú és egy nagy elemszámú csoportra bomlik a megfigyelt minta.

\section{7. táblázat}

A kártyás fizetési mód arányosított jellemzői alapján képzett települési klaszterek

\begin{tabular}{c|c|c|c|c} 
Klaszterszám & Csoport elemszáma & $\begin{array}{c}\mathbf{1} \mathbf{0 0 0} \text { före jutó } \\
\text { POS-terminálok } \\
\text { átlagos száma }\end{array}$ & $\begin{array}{c}\mathbf{1} \text { före jutó átlagos } \\
\text { kártyás forgalom }\end{array}$ & $\begin{array}{c}\mathbf{1} \text { POS-terminálra } \\
\text { jutó átlagos } \\
\text { forgalom }\end{array}$ \\
\hline $\mathbf{1}$ & 6 & 9,0 & 1284,4 & 162919,2 \\
\hline $\mathbf{2}$ & 5 & 18,1 & 11167,6 & 607041,0 \\
\hline $\mathbf{3}$ & 2104 & 5,9 & 27,9 & 3877,3 \\
\hline $\mathbf{4}$ & 324 & 9,7 & 247,5 & 24556,7 \\
\hline
\end{tabular}

Forrás: A GVH adatai alapján számítva

Az első két csoport jól elkülöníthető. A 2. csoportba tartozó településekre jellemző a fejlett kártyarendszer, azaz az arányaiban kiemelkedően magas POS-terminál-szám, egy főre jutó forgalom és egy POS-ra jutó forgalom (lásd 7. táblázat). Az 1. csoportban alacsonyabb az 1000 före jutó POS-terminálok száma, azonban az egy före jutó forgalom és az egy POS-terminálra jutó forgalom magasnak tekinthető, azaz intenzívebb a kártyahasználat, mint azt az elfogadói hálózat fejlettsége indokolná. Tehát ebbe a csoportba az arányaiban kevés POS-terminálon magas forgalmat generáló települések kerültek. A 3., legnagyobb elemszámú klaszter településeire jellemző az alacsony POS-ellátottság és az alacsony forgalom, ide a kicsi és kevésbé fejlett települések tartoznak. A 4. csoport településeire viszonylag magas POS-szám és alacsony forgalom jellemző, azaz hiába fejlett az elfogadói hálózat, egyéb okok - például általában az alacsony kiskereskedelmi forgalom, a kevésbé kiterjedt bolthálózat vagy a kártyabirtokosok alacsony aránya - miatt a telepített terminálokat kevéssé használják.

A 2. csoport tagjai: Törökbálint, Biatorbágy, Budaörs, Alsónémedi, Bicske. Az első három település az ország legfejlettebb települései közé tartozik, ezért nem meglepő, hogy magas a POS-terminál-lefedettség és a forgalom. Bicske és Budaörs ahogy fentebb is jeleztük - vélhetően a kedvező elhelyezkedésük miatt kerültek a csoportba, ami összhangban van Kuttor - Pál (2019) elemzésével is. Budapesthez való közelségük és a bevásárlóközpontokkal való ellátottságuk miatt sok budapesti választja vásárlásának célpontjául. Ez indokolhatja a magas POS-számot és a magas forgalmat is. 


\section{Következtetések}

Tanulmányunkban korábban nem elérhető adatok segítségével a hazai kártyás hálózat és forgalom területi jellemzőiről kívántunk részletes képet nyújtani. Míg az MNB mindezidáig, néhány kivételtől eltekintve elsősorban országos szinten vizsgálta a hazai pénzforgalom jellemzőit, addig a jelen elemzésben felhasznált adatbázis révén akár települési szintű sajátosságok megragadására is volt lehetőség. Célunk, hogy ezzel a vizsgálattal hozzájáruljunk a hazai elektronikus fizetési módok további elterjedéséhez, amely akár a kártyahasználaton is túlmutat. A kapott eredmények a jövőbeni azonnali fizetési megoldások további terjedéséhez is hozzájárulhatnak, hiszen különösen a kisebb, kártyaelfogadás szempontjából jelenleg kevésbé lefedett vállalkozások számára az új átutalási alapú fizetési mód akár olcsóbb elektronikus elfogadási alternativát is jelenthet. A kártyás elfogadói hálózat fejlettségére vonatkozó eredményeink azt mutatják, hogy jelentős területi eltérések vannak az országban ebből a szempontból, és főleg a keleti, nagyobb városoktól távolabb eső térségekben alacsony szintű még a kártyaelfogadás. Ez, ahogy az MNB adatai is mutatják, annak is köszönhető, hogy a kisebb méretű kereskedések számára a forgalomhoz viszonyítva csak jóval drágábban érhető el ez a szolgáltatás, nagyrészt annak köszönhetően, hogy a bankok így kezelik a kisebb kereskedők szegmenséhez kapcsolódó magasabb kockázatokat. Tehát épp ebben a körben lehet fontos az azonnali fizetés megjelenése, mely nagyban hozzájárulhat a pénzforgalmi szempontból kevésbé fejlett észak-magyarországi és alföldi régiók, illetve a kisebb községek fejlődéséhez. Hasonlóan kedvező lehet még az állami POS-telepítési program további folytatása, ill. bővítése, de elképzelhető az is, hogy a kereskedelmi elfogadóhelyek meghatározott és fokozatosan bővülő körének kötelezően előírják az elektronikus fizetési lehetőség biztosítását.

A lakosság kártyabirtoklása szempontjából következtetéseink megerősítik a témában 2014-ben lefolytatott legutóbbi MNB-felmérés (Ilyés - Varga 2015) eredményeit. Számottevően befolyásolja a háztartások kártyalefedettségét a háztartásfő iskolai végzettsége, életkora, ill. szociális helyzete. A korábbi felméréshez képest ugyanakkor a nagyobb minta miatt lehetőség volt a területi jellemzők részletesebb elemzésére is. Ennek eredményei megerősítik a kezdeti várakozásokat, hogy a Budapesttel kiegészített közép-magyarországi régió tekinthető a legfejlettebbnek ezen a téren, legrosszabb helyzetben pedig az Észak-Alföldön lakók vannak. Településtípusokat tekintve a községekben és kisebb városokban is alacsonyabb a háztartások kártyalefedettsége Budapesthez képest, kisebb az eltérés ugyanakkor a korábbi vizsgálattól abban, hogy az általunk vizsgált adatbázis alapján a megyeszékhelyeken viszont magasabb ez az arány, mint a fövárosban.

A kártyás forgalom terén is megmutatkozik az elfogadói hálózat terén jelentkező nagyfokú koncentráció a nagyvárosok és a fontosabb turisztikai desztinációk körül, a főváros mellett pedig Északnyugat-Magyarország emelendő ki, mint a legnagyobb 
mértékben kártyát használó terület. Vizsgálataink azt mutatták, hogy a kártyás forgalmat szignifikánsan növeli az elfogadói hálózat bővülése, ami megmutatja többek között a Pénzügyminisztérium által elindított országos POS-terminál-telepítési programok jelentőségét is. Kiemelendő még a munkaerőpiaci tényezők hatása, azaz a munkanélküliek, illetve a foglalkoztatottak aránya is szignifikáns befolyásoló tényezőt jelent a kártyás forgalom szempontjából. Ez egyrészt utalhat a kártyabirtokosi (kibocsátói) oldal fontosságára, másrészt az egyes területek általános gazdasági fejlettségére is.

Ahogy a fentiekben már jeleztük, elemzésünk esetében korlátot jelentett a modellekbe bevonható, a megfelelő bontásban elérhető magyarázó változók viszonylag szűk köre. Így egy későbbi, megismételt területi elemzés nagyban javíthatja az eredményt, amennyiben bővülni fog a most rendelkezésre álló adatok köre, pl. települési szintű jövedelmi vagy kiskereskedelmi forgalomra vonatkozó adatokkal, valamint a kártyás fizetések darabszámára vonatkozó adatokkal. A jövőben az online pénztárgépek adatai alapján, illetve kérdőívek segítségével újabb releváns adatokhoz juthatunk, aminek segítségével még pontosabb eredményeket kaphatunk. Másrészt míg jelen elemzésben csak keresztmetszeti szempontból tudtuk vizsgálni a kártyaelfogadói hálózat területi jellemzőit, esetleges újabb adatszolgáltatások révén mód lehet arra, hogy ennek időbeli változását is bemutassuk.

\section{Felhasznált irodalom}

Benedek, D. - Elek, P. - Köllö, J. (2013): Tax Avoidance, Tax Evasion, Black and Grey Employment. In: Fazekas, K. - Benczúr, P. - Telegdy, Á. (szerk.): The Hungarian Labour Market, Review and Analysis. Institute of Economics, Hungarian Academy of Sciences, Budapest.

Braithwaite, V. - Schneider, F. - Reinhart, M. - Murphy, K. (2002): Charting the Shoals of the Cash Economy. In: Braithwaite, V. (ed.): Taxing Democracy. Ashgate Publishing Ltd.

Deutsche Bundesbank (2019): Cash demand in the shadow economy. Deutsche Bundesbank Monthly Report March 2019.

Esselink, H. - Hernandez, L. (2017): The use of cash by households in the euro area. ECB Occasional Paper Series No. 201, European Central Bank.

Európai Központi Bank (EKB): Statisztikai adatbázis, 1 millió före jutó POS-terminál. Letöltve: 2019. július 29.

Greene, C. - Stavins, J. (2018): The 2017 Diary of Consumer Payment Choice. Research Data Reports No. 18-5, Federal Reserve Bank of Atlanta.

Helmeczi István (2010): A magyarországi pénzforgalom térképe. MNB-tanulmányok 84., Magyar Nemzeti Bank. 
Ilyés Tamás - Varga Lóránt (2015): Mutasd, mivel fizetsz, megmondom, ki vagy - A pénzforgalmi szokásokat befolyásoló szociodemográfiai tényezók. Hitelintézeti Szemle, 14(2): 26-61. https://hitelintezetiszemle.mnb.hu/letoltes/2-ilyes-varga.pdf

Ilyés Tamás - Varga Lóránt (2018): A kereskedők fizetésikártya-elfogadása Magyarországon $a z$ online pénztárgépek adatai alapján. Hitelintézeti Szemle, 17(1): 83-109. http://doi. org/10.25201/HSZ.17.1.83109

Jonker, N. - Hernandez, L. - de Vree, R. - Zwaan, P. (2018): From cash to cards: how debit card payments overtook cash in the Netherlands. N.V. Occasional Studies Volume 16-1, De Nederlandsche Bank.

Kovács Sándor Zsolt (2017): Város-vidék-kapcsolat a magyar pénzintézet-hálózatban. Területi Statisztika, 57(5): 495-511

Kuttor Dániel - Pál Zsolt (2019): A hazai fizetési forgalom területi aspektusa. Területi Statisztika, 59(1): 49-68. https://doi.org/10.15196/TS590103

MNB (2019): Pénzforgalmi táblakészlet. Magyar Nemzeti Bank. Letöltve: 2019. június 6.

Pál Zsolt (2014): A magyarországi bankközi klíringrendszer múködésének vizsgálata az elszámolás modernizációjának tükrében. PhD értekezés, Miskolci Egyetem Gazdaságtudományi Kar, Vállalkozáselmélet és gyakorlat Doktori Iskola.

Rochet, J.-Ch. - Tirole, J. (2003): An Economic Analysis of the Determination of Interchange Fees in Payment Card Systems. Review of Network Economics, 2(2): 69-79. https://doi. org/10.2202/1446-9022.1019

Rogoff, K.S. (2017): The curse of cash. Princeton University Press. https://doi.org/10.2307/j. ctvc77m90

Schmiedel, H. - Kostova, G. - Ruttenberg, W. (2012): The social and private costs of retail payment instruments. ECB Occasional Paper Series No. 137, European Central Bank.

Seitz, F. - Reimers, H. - Schneider, F. (2018): Cash in Circulation and the Shadow Economy: An Empirical Investigation for Euro Area Countries and Beyond. CESifo Working Paper Series 7143, CESifo Group Munich.

Simon Béla - Valentiny Ádám (2016): Miből élünk? Az első átfogó hazai háztartási vagyonfelmérés bemutatása. Statisztikai Szemle, 94(7): 717-735. https://doi.org/10.20311/ stat2016.07.hu0717

Turján Anikó - Divéki Éva - Keszy-Harmath Zoltánné - Kóczán Gergely - Takács Kristóf (2011): Semmi sincs ingyen: A föbb magyar fizetési módok társadalmi költségének felmérése. MNB-tanulmányok 93, Magyar Nemzeti Bank.

Végső Tamás - Belházyné Illés Ágnes - Bódi-Schubert Anikó (2018): Készpénz vagy kártya? A magyar lakosság fizetési szokásainak feltáró elemzése. Pénzügyi Szemle, 2018(4): 455-479. 


\section{Melléklet}

8. ábra

A kártyás fizetési mód jellemzői alapján képzett települési klaszterek

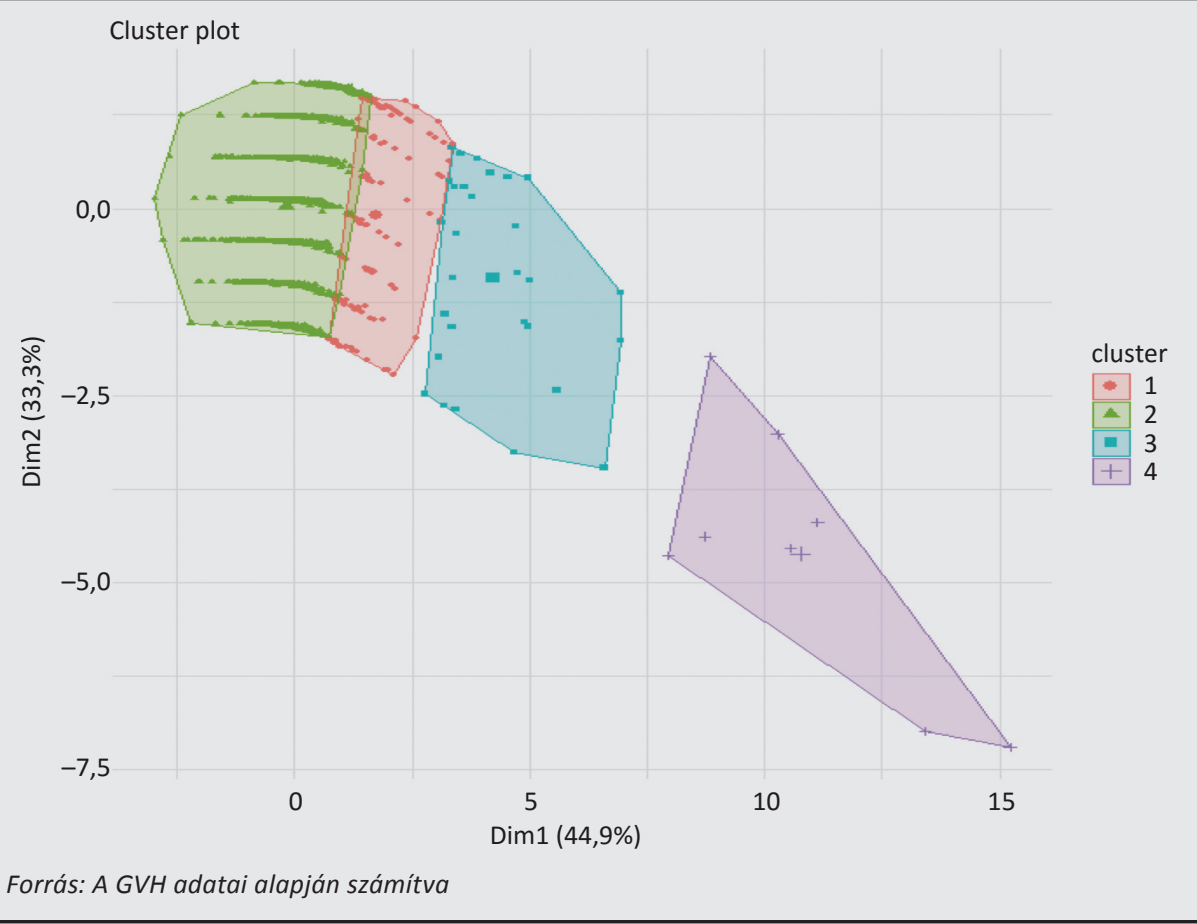

